\title{
Use of a risk factor and dietary calcium questionnaire in predicting bone density and subsequent bone loss at the menopause
}

\author{
Departments of \\ Environmental and \\ Preventive Medicine \\ and Rheumatology, \\ St Bartholomew's \\ Hospital Medical \\ College, London EC1, \\ United Kingdom \\ T D Spector \\ Bone and Joint \\ Research Unit \\ The London Hospital \\ Medical College, \\ London E1, \\ United Kingdom \\ A C Edwards \\ P W Thompson \\ Correspondence to: \\ Dr T D Spector, \\ Department of \\ Rheumatology, \\ St Bartholomew's \\ Hospital Medical College, \\ Charterhouse Square, \\ London EC1M 6BQ, \\ United Kingdom. \\ Accepted for publication \\ 29 June 1992
}

\begin{abstract}
One hundred and thirty six healthy white females within 30 months of their last menstrual period (mean age 52 years) were examined to determine the usefulness of a risk factor questionnaire in predicting bone density and subsequent loss. Bone density was assessed at baseline and at 12 monthly intervals. None of the proposed risk factor variables with the exception of nulliparity correlated with the baseline spinal or femoral bone density. As a predictor of bone loss only drinking alcohol (more than four units/day) was significant. A risk factor score derived from the questionnaire before its administration did not correlate with baseline bone density or subsequent bone loss. In most normal women questioned soon after a natural menopause, an estimate of bone density and subsequent bone loss and hence osteoporotic risk cannot be reliably made using a simple risk factor questionnaire.
\end{abstract}

(Ann Rheum Dis 1992; 51: 1252-1253)

The sequelae of postmenopausal osteoporosis is an enormous and increasing problem in developed countries. ${ }^{1}$ In women bone loss is greatly accelerated by the decline in ovarian function at the menopause. ${ }^{2}$ Hormone replacement therapy with oestrogens initiated at the menopause is the mainstay of prevention, but does have some adverse effects and cannot be given to all menopausal women. One method of identifying women at high risk might be to use a simple risk factor questionnaire at the menopause.

There are a number of associated risk factors for low bone mass, with complex interactions. Probably the most important factor is early loss of ovarian function, either naturally or by an operation. A number of other risk factors including parity, smoking, family history, lean build, alcohol intake, lack of exercise, or insufficient dietary calcium also have been implicated. The aim of this study was to assess the usefulness of a risk factor questionnaire and a dietary calcium questionnaire in the selection of women at the menopause either with low initial bone mass or high rates of subsequent bone loss.

\section{Patients and methods}

We studied 136 white female volunteers attending a local ovarian cancer screening programme between 1987 and 1988 who had recently had their last menstrual period (median 20 months, range 4-30 months from last menstrual period), with a mean age of 52 years. All women had a natural menopause, intact ovaries, and had not used postmenopausal oestrogens. A risk factor questionnaire for white women was devised before the study which categorised women into two groups for each potential risk factor and included 12 simple questions believed to have strong associations with low bone density. In addition, a risk factor score was calculated before the study from a summation of these 12 factors. Those regarded as at high risk had a score of 3 or more on this scale. A dietary calcium questionnaire which had been previously validated was used to assess current and past (10 years ago) calcium intake. ${ }^{3}$ Bone density expressed as grams hydroxyapatite $/ \mathrm{cm}^{2}$ $\left(\mathrm{gHA} / \mathrm{cm}^{2}\right)$ was determined at two sites, the proximal femur and the lumbar spine (L2-L4), using a Novo-BMC Lab 22a dual photon absorptiometer with a reproducibility in our hands of less than $0.8 \%$ for the spine and $1.6 \%$ for the femur. ${ }^{4}$ Three consecutive measurements at 0,12 , and 24 months were obtained for 103 women at the spine and 89 at the femur. For each risk factor variable the mean baseline bone density of the groups was compared by Student's $t$ test and when one of the groups was small (less than 20 subjects), by the non-parametric Mann Whitney $U$ test. Single and multiple regression (with SPSS software) was used to examine the relations between the variables.

\section{Results}

The only significant distinguishing factor for baseline spinal bone density was nulliparity (mean bone density of the seven nulliparous women was 0.71 compared with 0.80 for parous women)(table). Although there was considerable variation the annual rates of bone loss were $2 \cdot 1$ and $1.3 \%$ for the spine and femur respectively. None of the risk factors was significantly associated with the bone density of the femur. No difference was noted for baseline bone density of the spine or femur for women when women with 'high' risk scores were compared with those with 'low' scores. No significant correlation was obtained for any of the risk factor variables after adjustment using multiple regression. The only individual risk factor that correlated with percentage annual bone loss at the spine was alcohol consumption greater or equal to 4 units/day $(p=0 \cdot 02)$. No correlation was found between current or past levels of calcium intake and the bone density of the spine or femur $(r=-0.01 ; r=-0.02)$ nor with subsequent bone loss $(r=-0 \cdot 13 ; r=-0 \cdot 11)$. When all the risk factor variables were entered into a 
Mean bone density and mean annual bone loss for spine by risk factor status

\begin{tabular}{|c|c|c|c|c|c|c|}
\hline \multirow[t]{2}{*}{ Risk factor ${ }^{*}$} & \multicolumn{3}{|c|}{ Spinal bone density } & \multicolumn{3}{|c|}{ Annual bone loss in spine (\%) } \\
\hline & $\begin{array}{l}\operatorname{Mean}(S D) \\
\left(\mathrm{gHA} / \mathrm{cm}^{2}\right) t\end{array}$ & $n$ & p Value & $\operatorname{Mean}(S D)$ & $n$ & p Value \\
\hline Menopause $<45$ years & $\begin{array}{l}+0.80(0.09) \\
-0.80(0.11)\end{array}$ & $\begin{array}{r}7 \\
129\end{array}$ & NS & $1.71(3.32)$ & $\begin{array}{r}3 \\
98\end{array}$ & NS \\
\hline Cheese $<1$ oz/week & $\begin{array}{l}-0.80(0.11) \\
+0.82(0.11) \\
-0.79(0.11)\end{array}$ & $\begin{array}{r}129 \\
30\end{array}$ & NS & $\begin{array}{l}2.21(2 \cdot 30) \\
2.21(3 \cdot 49) \\
2.07(2 \cdot 46)\end{array}$ & $\begin{array}{l}98 \\
25 \\
76\end{array}$ & NS \\
\hline Milk consumption $<1 / 2$ pint/week & $\begin{array}{l}+0.80(0.11) \\
-0.79(0.11)\end{array}$ & $\begin{array}{l}56 \\
80\end{array}$ & NS & $\begin{array}{l}1.78(2.59) \\
2.30(2.81)\end{array}$ & 38 & NS \\
\hline Fracture in last 10 years & $\begin{array}{l}+0.80(0.07) \\
-0.80(0.11)\end{array}$ & 12 & NS & $\begin{array}{l}3.18(1.75) \\
1.99(2.79)\end{array}$ & 91 & NS \\
\hline No regular exercise & $\begin{array}{l}+0.78(0.11) \\
-0.81(0.11)\end{array}$ & $\begin{array}{l}49 \\
86\end{array}$ & NS & $\begin{array}{l}2.43(2.96) \\
1.97(2.63)\end{array}$ & $\begin{array}{l}31 \\
67\end{array}$ & NS \\
\hline Nulliparity & $+0.71(0 \cdot 10)$ & $\begin{array}{r}7 \\
7\end{array}$ & $p=0.04$ & $2.90(2.82)$ & 4 & NS \\
\hline Smoking 10 cigs $/$ day for 10 years & $\begin{array}{l}-0.80(0.11) \\
+0.81(0.08) \\
-0.79(0.11)\end{array}$ & $\begin{array}{r}129 \\
15 \\
121\end{array}$ & NS & $\begin{array}{l}2.07(2 \cdot 74) \\
3.17(3.69) \\
1.99(2.60)\end{array}$ & $\begin{array}{l}97 \\
10 \\
91\end{array}$ & NS \\
\hline Alcohol $>4$ units daily for $>5$ years & $\begin{array}{l}+0.82(0.08) \\
-0.80(0.11)\end{array}$ & $\begin{array}{r}6 \\
130\end{array}$ & NS & $\begin{array}{l}4 \cdot 52(2 \cdot 06) \\
2 \cdot 00(2 \cdot 71)\end{array}$ & $\begin{array}{r}4 \\
97\end{array}$ & 0.04 \\
\hline Other illnesses & $\begin{array}{l}+0.80(0.06) \\
-0.80(0.11)\end{array}$ & $\begin{array}{r}3 \\
133\end{array}$ & NS & $\begin{array}{l}3.65(4 \cdot 17) \\
2.08(2.72)\end{array}$ & $\begin{array}{r}2 \\
99\end{array}$ & NS \\
\hline Reported loss of height & $\begin{array}{l}+0.79(0.13) \\
-0.80(0.11)\end{array}$ & 23 & NS & $2.39(2.23)$ & $\begin{array}{l}15 \\
86\end{array}$ & NS \\
\hline Weight less than $52.5 \mathrm{~kg}$ & $\begin{array}{l}+0.80(0.10) \\
-0.80(0.11)\end{array}$ & $\begin{array}{r}8 \\
128\end{array}$ & NS & $\begin{array}{l}2.64(2.94) \\
2.07(2 \cdot 72)\end{array}$ & $\begin{array}{r}7 \\
94\end{array}$ & NS \\
\hline Relative older than 45 years with fracture & $\begin{array}{l}+0.82(0.12) \\
-0.80(0.11)\end{array}$ & $\begin{array}{r}17 \\
119\end{array}$ & NS & $\begin{array}{l}1 \cdot 79(2 \cdot 45) \\
2 \cdot 14(2 \cdot 79)\end{array}$ & $\begin{array}{l}11 \\
90\end{array}$ & NS \\
\hline $\begin{array}{l}\text { High risk score }(3+) \\
\text { Low risk score }(3-)\end{array}$ & $\begin{array}{l}0.80(0.10) \\
0.76(0.11)\end{array}$ & $\begin{array}{l}51 \\
85\end{array}$ & NS & $\begin{array}{l}2 \cdot 15(2 \cdot 38) \\
2 \cdot 08(2 \cdot 91)\end{array}$ & $\begin{array}{l}35 \\
66\end{array}$ & NS \\
\hline
\end{tabular}

*+=risk factor present; - =risk factor absent.

tGrams hydroxyapatite per square centimetre.

multiple regression model, the $\mathbf{R}^{2}$ value for the explained variation in bone density was only $11 \%$ for the spine and $17 \%$ for the femur. Similarly values for the $\mathbf{R}^{2}$ for bone loss were 24 and $12 \%$ respectively.

\section{Discussion}

This study has not shown any predictive value of a risk factor or a dietary calcium questionnaire in selecting women with a natural menopause at subsequent risk of osteoporosis. None of the women studied had been treated with steroids or thyroxine over a long period of time or had undergone a gastrectomy. Although suggested as risk factors, the rarity of these factors in this age group makes them of little use in a population screening questionnaire.

It is possible that, by selecting different groups of risk factors, a questionnaire could have greater discrimination for bone density. Other studies have looked at a variety of risk factors in different groups of women compared with bone density..$^{5-7}$ In these studies, however, no combination of risk factors explained more than $33 \%$ of the variance of bone density. Two studies have also looked at the prediction of vertebral fractures with similarly poor results. ${ }^{89}$ The only other study to look at bone loss after the menopause found none of the risk factors to be of value in the prediction of bone density at the wrist 12 years later. ${ }^{10}$

In conclusion, in a study of healthy women soon after a natural menopause, we have found that risk factor profiles are not a useful substitute for bone density measurement in assessing osteoporotic risk. Measurements of bone density using densitometry techniques remain at present the only practical way of selecting women at risk of osteoporosis.

We thank Dr Ian Jacobs and Dr David Oram of the department of obstetrics and gynaecology at the London Hospital for help in of obstetrics and gynaecology at the London Hospital for help in recruiting the subjects, Dr Cyrus Cooper for initial discussions about the questionnaire, Dr M Nelson for supplying the dietary calcium programme and Dr Keith Britton and Ravin Sobnack of the department of nuclear medicine, St Bartholomew's Hospital for assistance with the dual photon scanning. This project was partly funded from a grant from Rorer Health Care Lid.

1 Boyce W J, Vessey M P. Rising incidence of fracture of the proximal femur Lancet 1985; i: 150-1.

2 proximal , Hart D M, Forrest C, Baird C. Prevention of spinal osteoporosis in oophorectomised women. Lancet spinal osteoporosis

3 Nelson M, Hague G F, Cooper C, Bunber V W. Calcium intake in the elderly: validation of a dietary questionnaire. fournal of Human Nutrition and Dietetics 1988; 1: 115-27.

4 Edwards A C, Spector T D, Sobnack R, Horrobin J, Britton $K$ E, Thompson $P$ W. Bone density measurements in the early menopause: comparison of hip and spine. Foumal of Bone and foint Mineral Research 1989; 4 (suppl 1): 192.

5 Stevenson J C, Lees B, Devenport M, Cust M P, Ganger K F. Determinants of bone density in normal women: risk factors for future osteoporosis? BMF 1989; 298: 924-8.

6 Elders $\mathrm{P}$ M, Netelenbos J C, Lips P, et al. Perimenopausal bone mass and risk factors. Bone Miner 1989; 7: 289-99.

7 Slemenda C W, Hui S L, Longcope C, Wellman H, Johnston C C. Predictors of bone mass in perimenopausal women. C C. Predictors of bone mass in peri
Ann Intern Med 1990; 112: 96-101.

8 Van Hemert A M, Vandenbroucke J P, Birkenhager J C, Valkenburg H A. Prediction of osteoporotic fractures in the general population by a fracture risk score. Am $\mathcal{J}$ Epidemiol 1990; 132: 123-35.

9 Cooper C, Shah S, Hand D J, et al. Screening for vertebra osteoporosis using individual risk factors. Osteoporosis In 1991; 2: 48-53.

10 Hansen M A, Overgaard K, Riis B J, Christiansen C. Potential risk factors for development of postmenopausal osteoporosis - examined over a 12 year period. Osteoporosis Int 1991; 1: 93-102. 